\title{
Energy Production from Zoo Animal Wastes
}

February 2003

\author{
Prepared by \\ K. Thomas Klasson \\ Nhuan (John) P. Nghiem
}




\title{
DOCUMENT AVAILABILITY
}

Reports produced after January 1, 1996, are generally available free via the U.S. Department of Energy (DOE) Information Bridge:

Web site: http://www.osti.gov/bridge

Reports produced before January 1, 1996, may be purchased by members of the public from the following source:

\author{
National Technical Information Service \\ 5285 Port Royal Road \\ Springfield, VA 22161 \\ Telephone: 703-605-6000 (1-800-553-6847) \\ TDD: $703-487-4639$ \\ Fax: 703-605-6900 \\ E-mail: info@ntis.fedworld.gov \\ Web site: http://www.ntis.gov/support/ordernowabout.htm
}

Reports are available to DOE employees, DOE contractors, Energy Technology Data Exchange (ETDE) representatives, and International Nuclear Information System (INIS) representatives from the following source:

Office of Scientific and Technical Information

P.O. Box 62

Oak Ridge, TN 37831

Telephone: $865-576-8401$

Fax: 865-576-5728

E-mail: reports@adonis.osti.gov

Web site: http://www.osti.gov/contact.html

\begin{abstract}
This report was prepared as an account of work sponsored by an agency of the United States Government. Neither the United States government nor any agency thereof, nor any of their employees, makes any warranty, express or implied, or assumes any legal liability or responsibility for the accuracy, completeness, or usefulness of any information, apparatus, product, or process disclosed, or represents that its use would not infringe privately owned rights. Reference herein to any specific commercial product, process, or service by trade name, trademark, manufacturer, or otherwise, does not necessarily constitute or imply its endorsement, recommendation, or favoring by the United States Government or any agency thereof. The views and opinions of authors expressed herein do not necessarily state or reflect those of the United States Government or any agency thereof.
\end{abstract}


ORNL/TM-2003/51

\title{
ENERGY PRODUCTION FROM ZOO ANIMAL WASTES
}

K. Thomas Klasson Nhuan (John) P. Nghiem

Date Published: February 2003

\author{
Prepared by \\ OAK RIDGE NATIONAL LABORATORY \\ P.O. Box 2008 \\ Oak Ridge, Tennessee 37831-6285 \\ managed by \\ UT-Battelle, LLC \\ for the \\ U.S. DEPARTMENT OF ENERGY \\ under contract DE-AC05-00OR22725
}





\section{CONTENTS}

Page

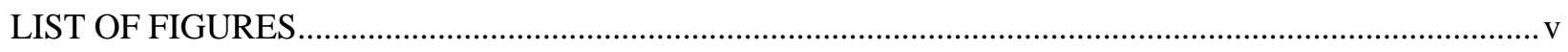

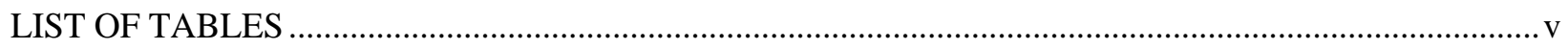

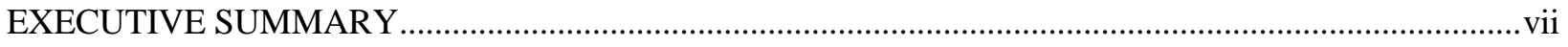

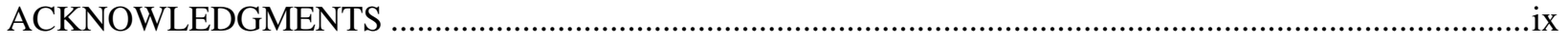

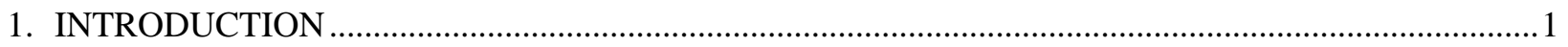

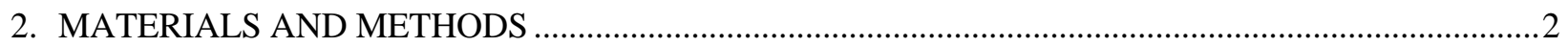

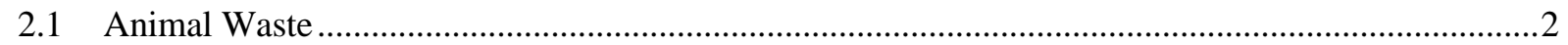

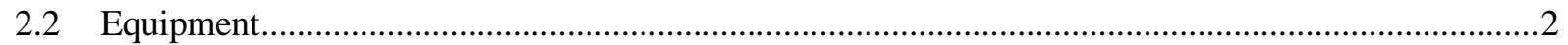

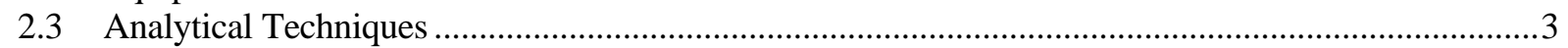

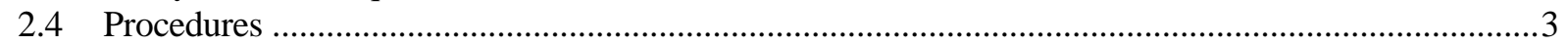

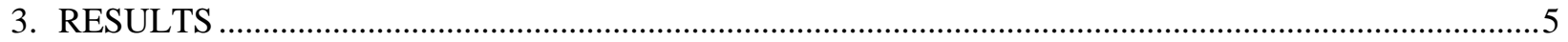

3.1 Estimated Biogas Energy Availability at the Knoxville Zoo ..........................................................

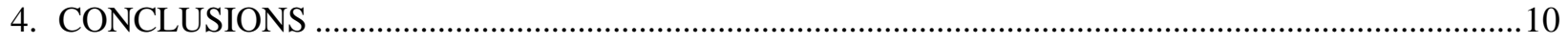

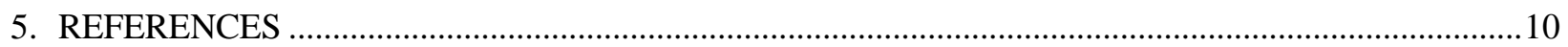





\section{LIST OF FIGURES}

Figure

Page

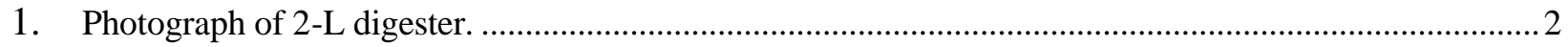

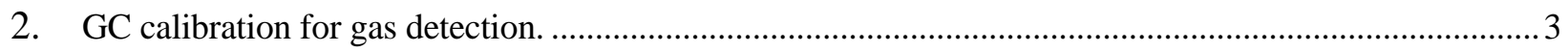

3. Cumulative gas volume data collected from starter cultures. ................................................................ 4

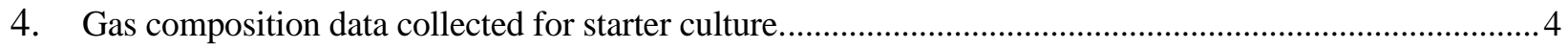

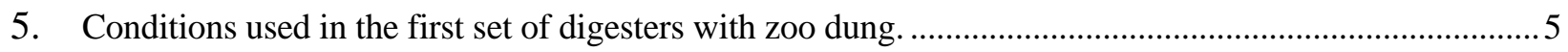

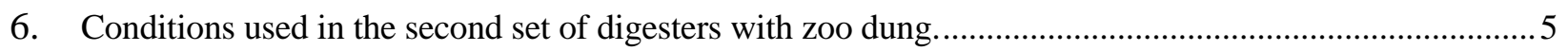

7. Biogas production rate for digesters with or without starters............................................................. 6

8. Methane production rate for digesters with or without starters......................................................... 6

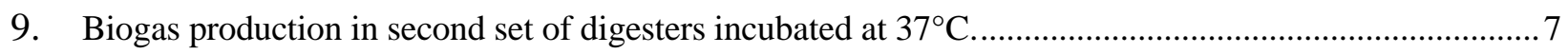

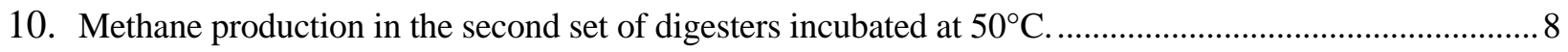

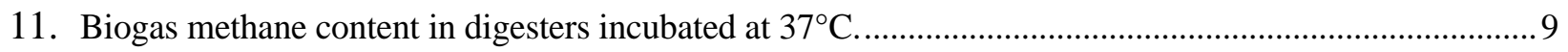

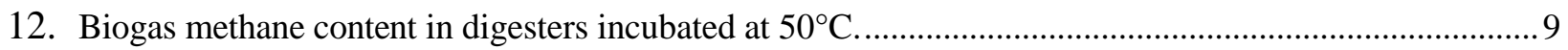

\section{LIST OF TABLES}

Table

Page

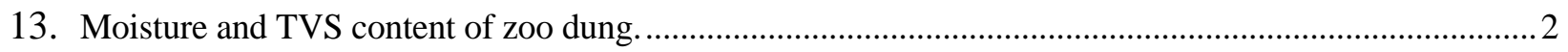

14. Biogas and methane yields in digesters with and without starters ...................................................... 7

15. Biogas and methane yields in digesters with and without nitrogen supplement at two different incubation

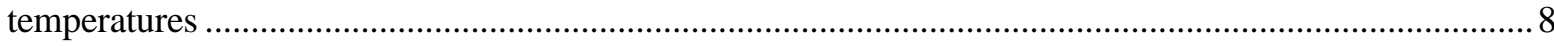





\section{EXECUTIVE SUMMARY}

Elephant and rhinoceros dung was used to investigate the feasibility of generating methane from the dung. The Knoxville Zoo produces 30 cubic yards $\left(23 \mathrm{~m}^{3}\right)$ of herbivore dung per week and cost of disposal of this dung is $\$ 105 /$ week. The majority of this dung originates from the Zoo's elephant and rhinoceros population. The estimated weight of the dung is 20 metric tons per week and the methane production potential determined in experiments was $0.033 \mathrm{~L}$ biogas/g dung $\left(0.020 \mathrm{~L} \mathrm{CH}_{4} / \mathrm{g}\right.$ dung $)$, and the digestion of elephant dung was enhanced by the addition of ammonium nitrogen. Digestion was better overall at $37^{\circ} \mathrm{C}$ when compared to digestion at $50^{\circ} \mathrm{C}$. Based on the amount of dung generated at the Knoxville Zoo, it is estimated that two standard garden grills could be operated $24 \mathrm{~h}$ per day using the gas from a digester treating 20 metric ton herbivore dung per week. 



\section{ACKNOWLEDGMENTS}

This work was supported by the Oak Ridge National Laboratory's State Partnership Program and administered by the U.S. Department of Energy's Energy Efficiency and Renewable Energy Program.

The original idea for this work was proposed by John Sicard of Knoxville, TN, who was a construction consultant for a renovation project at the Knoxville Zoo. 



\section{INTRODUCTION}

Until the 1960's, coal was the single most important source of the world's primary energy. In the late 1960's it was overtaken by oil; but forecasts predict that coal will again become the major primary energy source at some stage during the first half of the next century. In 1998, the production of hard coal in the United States was 936 million tons (Mt). Coal is the major fuel used for generating electricity in the United States, accounting for $56 \%$ of the electricity generated in 1998 .

One approach to reduce the nation's dependence on coal and other fossil fuels is for utility companies to cofire (either directly or indirectly) a percentage of their total fuel requirements using biomass. Recognizing the tremendous coal requirements to produce electricity and process steam in the United States, even small biomass co-firing rates would have a significant impact both environmentally and economically.

Furthermore, co-firing with biomass supports policies of the Clean Air and Energy Policy Act, since biomass represents a clean fuel source which can

- reduce $\mathrm{SO}_{\mathrm{X}}$ emissions (biomass contains very little sulfur),

- reduce methane (formed in degradation of unused biomass) released into the atmosphere, and

- reduce $\mathrm{NO}_{\mathrm{X}}$ emissions (biomass contains less nitrogen than coal). ${ }^{1}$

A source of biomass material for direct or indirect co-firing with coal that has not received much attention is zoo animal waste. Nearly every metropolitan city in the United States has a zoo, and the amount of wastes produced by the animals in these zoos and the energy that can be derived from them is quite significant. For example, for the zoo in a mid-size city like Knoxville, Tennessee, animal waste production is about 20 metric tons per week. Animal wastes have an energy value for direct combustion, just like many other organic compounds such as solid wastes from municipalities. There has been very little experience in the direct combustion of animal wastes, either by themselves or as a supplement to some other organic fuel source such as coal. Discussions with the main power supplier in the area, Tennessee Valley Authority, indicated that the type of waste generated by the zoo is not compatible with the type of burners used in the local vicinity. However, indirect co-firing of gases from an anaerobic digestion lagoon may be feasible. A more attractive option is to locate a digester at the zoo for energy and/or heat generation.

The production of methane from various forms of biomass has recently been reviewed. ${ }^{2}$ Methane yields from biomass range on average from 0.3 to $0.4 \mathrm{~m}^{3}$ methane $/ \mathrm{kg}$ volatile solids. Methane yields from animal waste have also been studied, although these studies have targeted domesticated animals. When compared to other types of biomass, animal waste has the greatest potential for methane production. ${ }^{3}$ Some encouraging results exist for the use of large-animal waste at the Baltimore Zoo, where a private contractor built two digesters in 1974 and 1980 at the zoo for demonstration purposes. That system produced $1.4 \mathrm{~m}^{3}$ gas per day, ${ }^{4}$ and the power generated was used on site. The Associated Press has also reported on the generation of electricity from elephant dung in Thailand. ${ }^{5}$ 


\section{MATERIALS AND METHODS}

\subsection{ANIMAL WASTE}

Elephant and rhinoceros dung was obtained in August 2000 from the Knoxville Zoo packaged in several layers of plastic. The dung was refrigerated at $4^{\circ} \mathrm{C}$ prior to use. The appearance of the two types of dung was very similar in structure and coloring, with the elephant dung being slightly greener in appearance. Both dung types were solids containing a large amount of undigested whole fiber. The moisture (determined by drying at $105^{\circ} \mathrm{C}$ for $24 \mathrm{~h}$ ) and total volatile solids (TVS) content (heating to $550^{\circ} \mathrm{C}$ for $45 \mathrm{~min}$ ) are shown in Table 1 .

Table 1. Moisture and TVS content of zoo dung.

\begin{tabular}{lccc}
\hline Dung Type & $\begin{array}{c}\text { Moisture } \\
\text { Content }(\%)\end{array}$ & $\begin{array}{c}\text { TVS } \\
\text { (g/g dry) }\end{array}$ & $\begin{array}{c}\text { TVS } \\
\text { (g/g wet) }\end{array}$ \\
\hline Elephant & 83 & 0.91 & 0.15 \\
Rhinoceros & 81 & 0.83 & 0.16 \\
\hline
\end{tabular}

In addition to the zoo dung, cow manure was collected as digestion starter from a local farmer. This manure was also refrigerated prior to use.

\subsection{EQUIPMENT}

The anaerobic digestions were carried out in sealed glass flasks with an attached gas bag to allow for collection of generated gases. The sizes of the glass flasks were between nominal $250 \mathrm{~mL}$ to $2 \mathrm{~L}$. The liquid content in the digesters was approximately $100 \mathrm{~mL}$ (for $250-\mathrm{mL}$ digesters) and $1.8 \mathrm{~L}$ (for 2-L digesters). A photograph of a 2-L digester is shown in Fig. 1. The digesters were placed in a temperature-controlled environment and the content of the digesters was not mechanically mixed.

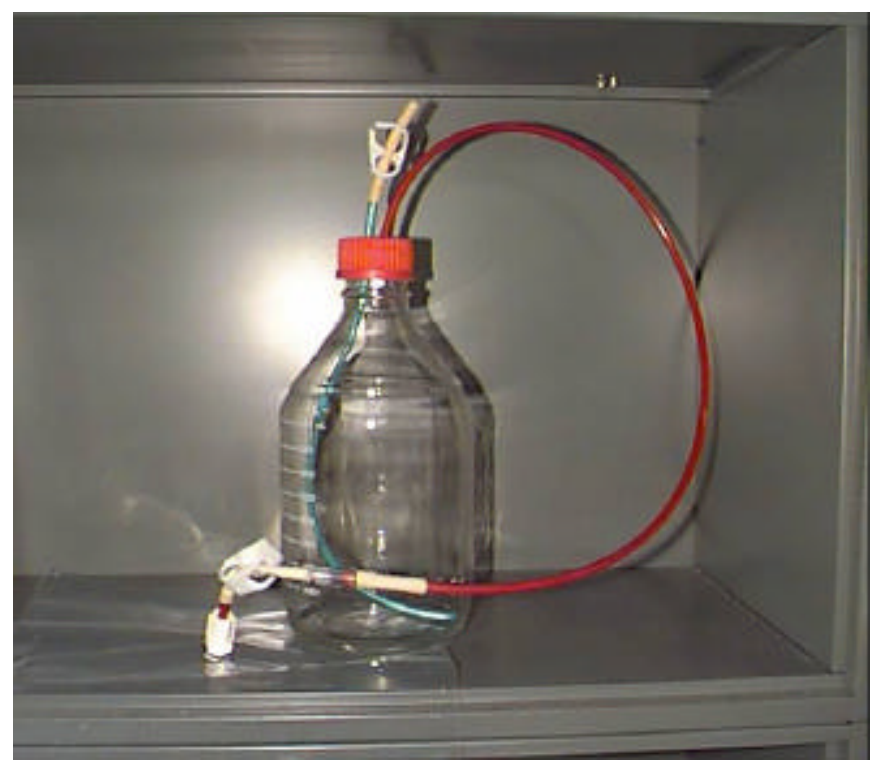

Fig. 1. Photograph of 2-L digester. 


\subsection{ANALYTICAL TECHNIQUES}

Gas samples were periodically collected using a gas-tight syringe and a sampling port in the gas bag. The gas sample $(150 \mu \mathrm{L})$ was injected in duplicate into a Series II 5890 Hewlett Packard (Avondale, PA) gas chromatograph (GC) with a $0.53 \mathrm{~mm} \times 30 \mathrm{~m}$ GS-Q phase capillary column (J\&W Scientific, Folsom, CA). The injector, oven, and thermal conductivity detector (TCD) temperatures were 125,50 , and $250^{\circ} \mathrm{C}$, respectively. The carrier gas (helium) flow rate through the column was $4.1 \mathrm{~mL} / \mathrm{min}$. The sample was injected in a split mode with approximately $12 \%$ of the sample going through the column. The make-up and reference gas for the TCD was helium.

Gas chromatograph calibration of methane $\left(\mathrm{CH}_{4}\right)$ and carbon dioxide $\left(\mathrm{CO}_{2}\right)$ gases was performed by injecting different volumes $(25-150 \mu \mathrm{L})$ of pure gases. The calibration was linear-peak area was proportional to the amount of gas injected (Fig. 2).

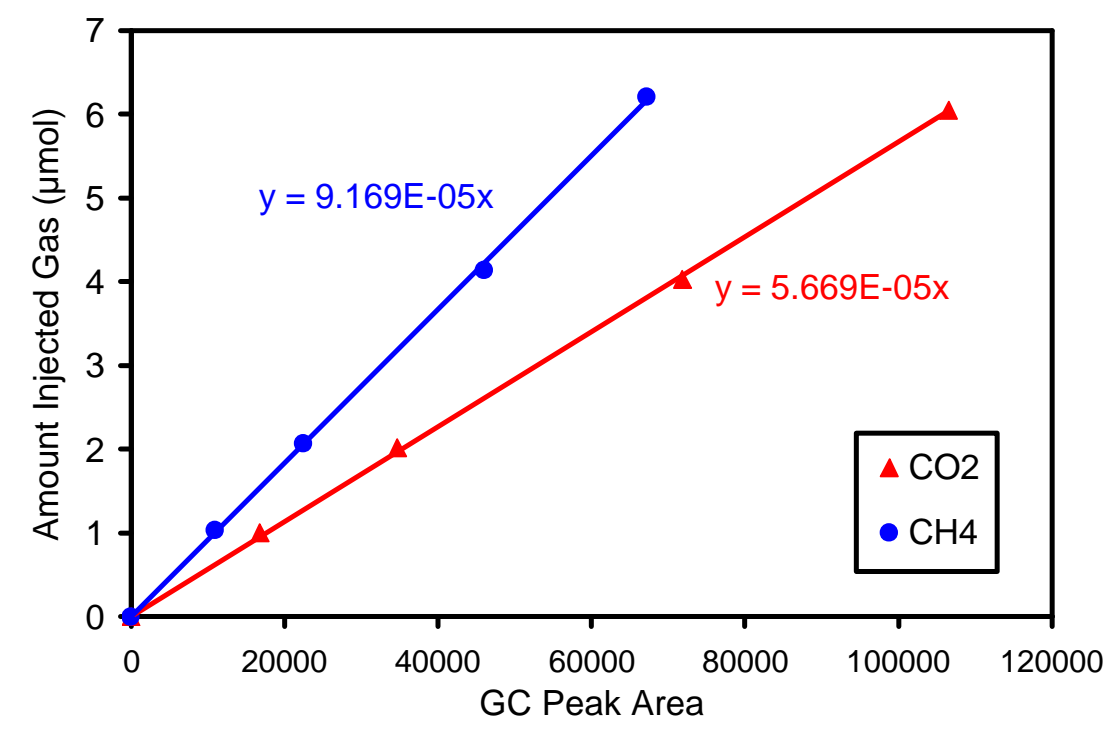

Fig. 2. GC calibration for gas detection.

The volume of gas produced in the digesters was measured by allowing the gas collected in the bag to flow into a graduated cylinder filled with water and measuring the volume of displaced water.

\subsection{PROCEDURES}

Starter cultures were prepared using cow manure and tap water in 2-L digesters at two different solids concentrations, $25 \%$ and $50 \%$, based on wet manure. The digesters were incubated at $37^{\circ} \mathrm{C}$. The gas generation and gas composition in the gas are shown in Fig. 3 and Fig. 4. for the two types of starter cultures Because of the more rapid generation of gas in the digester containing $25 \%$ solids, aliquots from this digester were used as the starter culture for new digesters with zoo dung. 


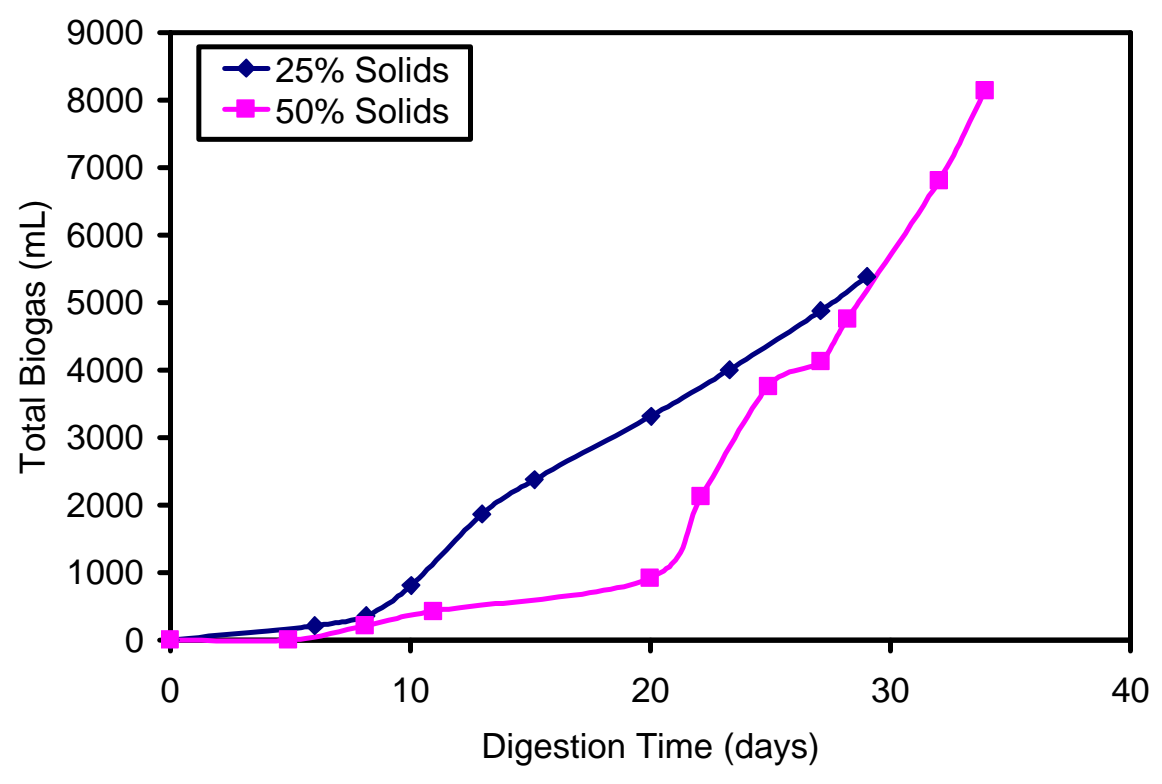

Fig. 3. Cumulative gas volume data collected from starter cultures.

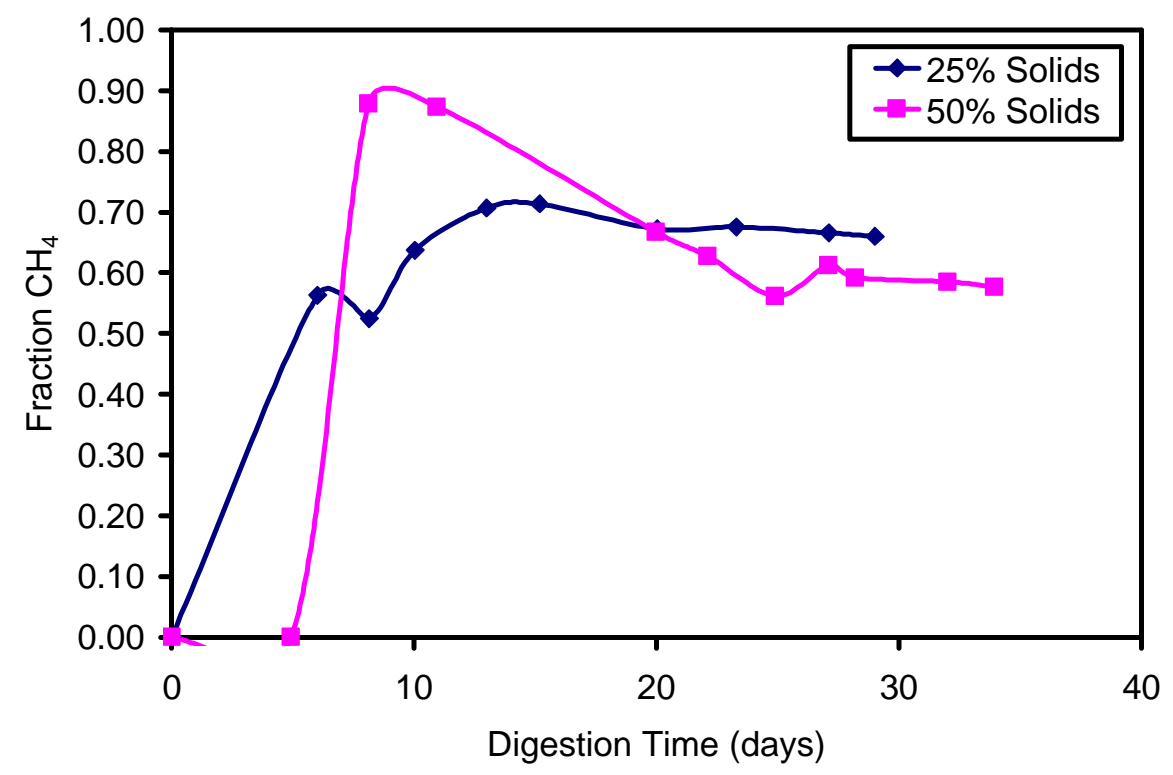

Fig. 4. Gas composition data collected for starter culture.

The next set of five digesters was started using zoo dung and tap water in the 250 -mL digesters. The wet solids concentration was $25 \%$ in all cases. Half of the digesters were started with $10 \%(\mathrm{w} / \mathrm{w})$ aliquots from the starter culture with $25 \%$ cow manure. A control digester was also prepared with the same amount of starter culture, but with no additional water or dung. This control digester accounted for the amount of gas produced from the starter culture itself. A depiction of the different digester conditions may be seen in Fig. 5 . All these digesters were incubated at $37^{\circ} \mathrm{C}$ and sampled periodically. 


\begin{tabular}{|c|c|}
\hline Elephant dung & $\begin{array}{l}\text { Elephant dung } \\
\text { with starter }\end{array}$ \\
\hline Rhinoceros dung & $\begin{array}{l}\text { Rhinoceros dung } \\
\text { with starter }\end{array}$ \\
\hline & \\
\hline
\end{tabular}

Fig. 5. Conditions used in the first set of digesters with zoo dung.

The next set of eight digesters was started using zoo dung and tap water (or tap water augmented with $1.34 \mathrm{~g} / \mathrm{L}$ ammonium chloride, $\mathrm{NH}_{4} \mathrm{Cl}$, to provide a source of nitrogen) in the 250 -mL digesters. The wet solids concentration was $25 \%$ in all cases. All the digesters were started with $3 \%$ (w/w) of starter from the digester with rhinoceros dung and cow manure starter from the previous set. Half of the digesters were incubated at $37^{\circ} \mathrm{C}$ and the other half were incubated at $50^{\circ} \mathrm{C}$. A depiction of the different digester conditions is shown in Fig. 6.

\begin{tabular}{|c|c|c|}
\hline $\begin{array}{c}\text { Elephant dung, 25\% } \\
37^{\circ} \mathrm{C}\end{array}$ & $\begin{array}{c}\text { Rhinoceros dung, 25\% } \\
37^{\circ} \mathrm{C}\end{array}$ & \multicolumn{2}{|c|}{} \\
\hline $\begin{array}{c}\text { Elephant dung, 25\% } \\
\text { Nitrogen supplement } \\
37^{\circ} \mathrm{C}\end{array}$ & $\begin{array}{c}\text { Rhinoceros dung, 25\% } \\
\text { Nitrogen supplement } \\
37^{\circ} \mathrm{C}\end{array}$ & \multicolumn{2}{|c|}{} \\
\hline & $\begin{array}{c}\text { Elephant dung, 25\% } \\
50^{\circ} \mathrm{C}\end{array}$ & $\begin{array}{c}\text { Rhinoceros dung, 25\% } \\
50^{\circ} \mathrm{C}\end{array}$ \\
\cline { 3 - 4 } & $\begin{array}{c}\text { Elephant dung, 25\% } \\
\text { Nitrogen supplement } \\
50^{\circ} \mathrm{C}\end{array}$ & $\begin{array}{c}\text { Rhinoceros dung, 25\% } \\
\text { Nitrogen supplement } \\
50^{\circ} \mathrm{C}\end{array}$ \\
\end{tabular}

Fig. 6. Conditions used in the second set of digesters with zoo dung.

\section{RESULTS}

The use of a starter culture from an active digester with cow manure shortened the lag time for new digesters. This may be noted in Fig. 7 and Fig. 8, where the biogas generation rate and the methane generation rate has been plotted as a function of the digestion time. The lag time for digesters with starters was on the order of a few days, while the lag time was on the order of 1 to 2 weeks without a starter. As noted from the results presented in the figures, the digester with just rhinoceros dung appeared to have a significantly lower biogas and methane production rate than what was noted in the other digesters. This result was attributed to a gas leak noted in this digester; the leak could not be sealed without compromising the experiment. Thus, it must be assumed that the measured rates in this digester were lower than the actual rates. In all cases, there was an initial spurt of gas production, early in the digestion time, when the easily degradable carbon sources are converted. After this initial spurt, the biogas and methane production rates were constant at $1.1 \mathrm{~L}$ gas $/ \mathrm{kg}$ wet dung/day and $0.03 \mathrm{~mol} \mathrm{CH}_{4} / \mathrm{kg}$ wet dung/day. Biogas and methane production dropped sharply after 35 days of digestion time. 


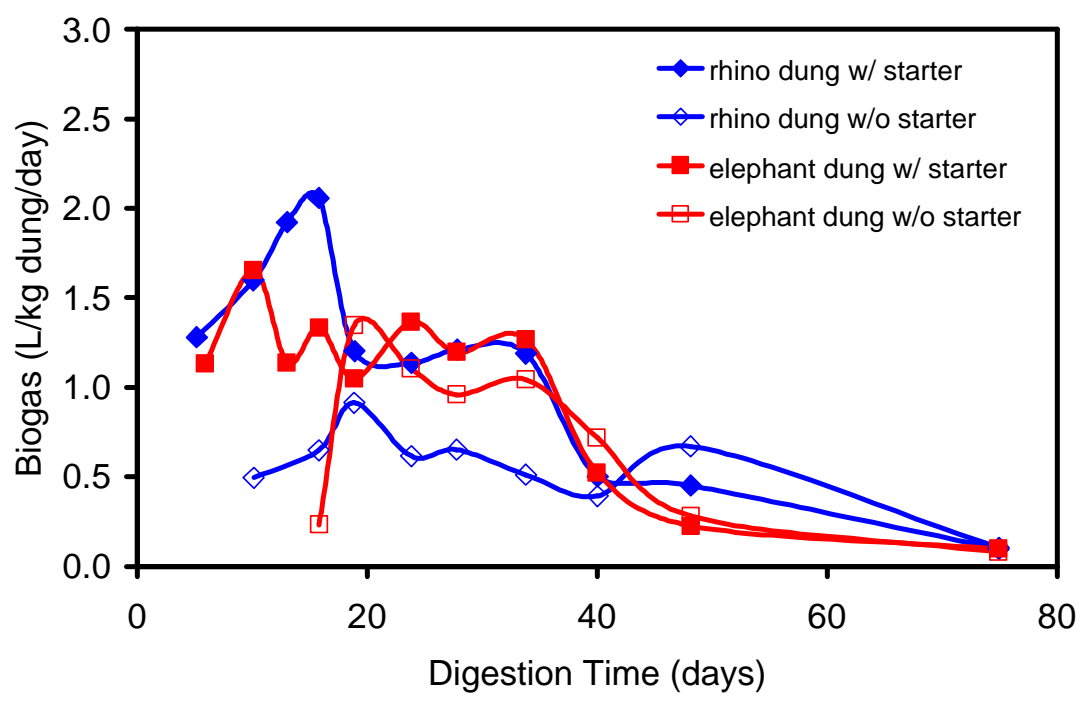

Fig. 7. Biogas production rate for digesters with or without starters.

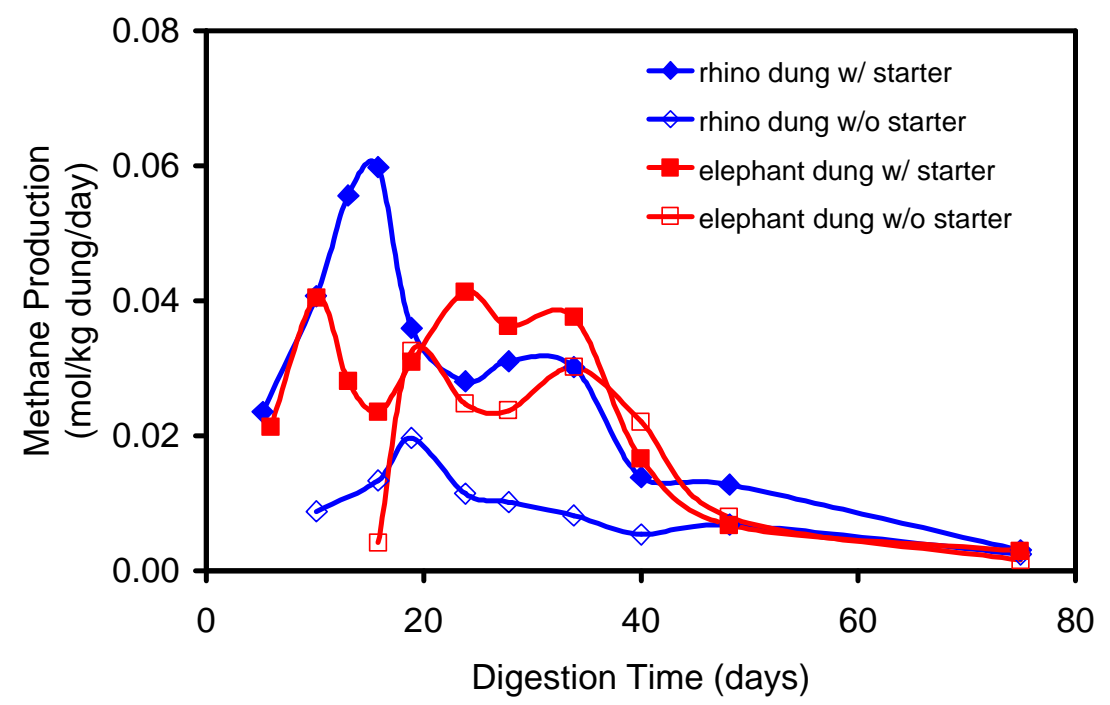

Fig. 8. Methane production rate for digesters with or without starters.

The biogas and methane yields are shown in Table 2. The benefit of using a starter is clearly seen in the yields. Both types of dung resulted in similar results a biogas yield on dung of $0.051-0.057 \mathrm{~L} / \mathrm{g}$. This compares favorably with the results obtained by Mandal and Mandal, who obtained 2.4-3.3 L gas from $150 \mathrm{~g}$ of "dense" animal dung, such as camel and horse dung. ${ }^{3}$ The yield of methane on TVS of $0.2 \mathrm{~L} \mathrm{CH}_{4} / \mathrm{g}$ TVS follows well those reported by Gunaseelan for average grasses in his review article. ${ }^{2}$ The final $\mathrm{pH}$ of the digesters at the end of the incubation period was 6.95-7.39. The control digester containing just starter did not produce significant biogas. 
Table 2. Biogas and methane yields in digesters with and without starters

\begin{tabular}{|c|c|c|c|c|c|c|c|}
\hline \multirow[b]{2}{*}{ Digester } & \multirow{2}{*}{$\begin{array}{l}\text { Dung } \\
\text { (g) }\end{array}$} & \multirow{2}{*}{$\begin{array}{l}\text { TVS } \\
\text { (g) }\end{array}$} & \multirow{2}{*}{$\begin{array}{l}\text { Biogas } \\
\left(\mathbf{L}_{\mathrm{STP}}\right)^{*}\end{array}$} & \multirow{2}{*}{$\begin{array}{c}\mathbf{C H}_{4} \\
\left(\mathrm{~L}_{\mathrm{STP}}\right)\end{array}$} & \multicolumn{3}{|c|}{ Yields } \\
\hline & & & & & (L biogas/g dung) & ( $\mathrm{L} \mathrm{CH}_{4} / \mathrm{g}$ dung) & $\left(\mathrm{L} \mathrm{CH}_{4} / \mathrm{g}\right.$ TVS $)$ \\
\hline $\begin{array}{l}\text { Rhinoceros dung } \\
\text { w/ starter }\end{array}$ & 37.5 & 6.1 & 2.12 & 1.24 & 0.057 & 0.033 & 0.20 \\
\hline $\begin{array}{l}\text { Rhinoceros dung } \\
\text { w/o starter }\end{array}$ & 37.5 & 6.1 & 1.16 & 0.44 & 0.031 & 0.012 & 0.072 \\
\hline $\begin{array}{l}\text { Elephant dung } \\
\text { w/ starter }\end{array}$ & 37.5 & 5.7 & 1.90 & 1.13 & 0.051 & 0.030 & 0.20 \\
\hline $\begin{array}{l}\text { Elephant dung } \\
\text { w/o starter }\end{array}$ & 37.5 & 5.7 & 1.21 & 0.68 & 0.032 & 0.018 & 0.12 \\
\hline
\end{tabular}

In order to potentially increase the biogas and methane yield on rhinoceros and elephant dung, nitrogen was supplemented to some of the digesters in the subsequent experiment. Elephant dung has been found to contain lower than optimal nitrogen content for methane generation. ${ }^{6}$ Nitrogen was added in the form of ammonia to achieve a carbon-to-nitrogen ratio of $25 \mathrm{~g} / \mathrm{g}$, which is considered in the optimal range. ${ }^{6}$ The effect of nitrogen addition and incubation at $37^{\circ} \mathrm{C}$ or $50^{\circ} \mathrm{C}$ may be seen in Fig. 9 and Fig. 10. As in the previous study, there was a high initial methane production rate, followed by a much slower rate. The digester with elephant dung was incubated at $50^{\circ} \mathrm{C}$ with supplemental nitrogen initially produced a small amount of biogas and the production halted for several weeks; then suddenly, gas was generated again.

The biogas and methane yields are shown in Table 3. The largest amount of gas was produced in the elephant dung digester supplemented with nitrogen and incubated at $37^{\circ} \mathrm{C}$. It is interesting to note that the amount of gas produced in this digester was less than the amount of gas produced in the digester with elephant dung and cow starter, incubated at $37^{\circ} \mathrm{C}$ (see Table 2). The digestion of rhinoceros dung did not appear affected by supplemented nitrogen, and the rhinoceros dung digester in the second set of experiments produced less biogas than the digester with rhinoceros dung and cow starter, incubated at $37^{\circ} \mathrm{C}$ (see Table 2). This indicates that the use of a blend of cow manure and zoo dung would yield more biogas and methane. The final $\mathrm{pH}$ of the digesters at the end of the incubation period was $\mathrm{pH} 8.3$.

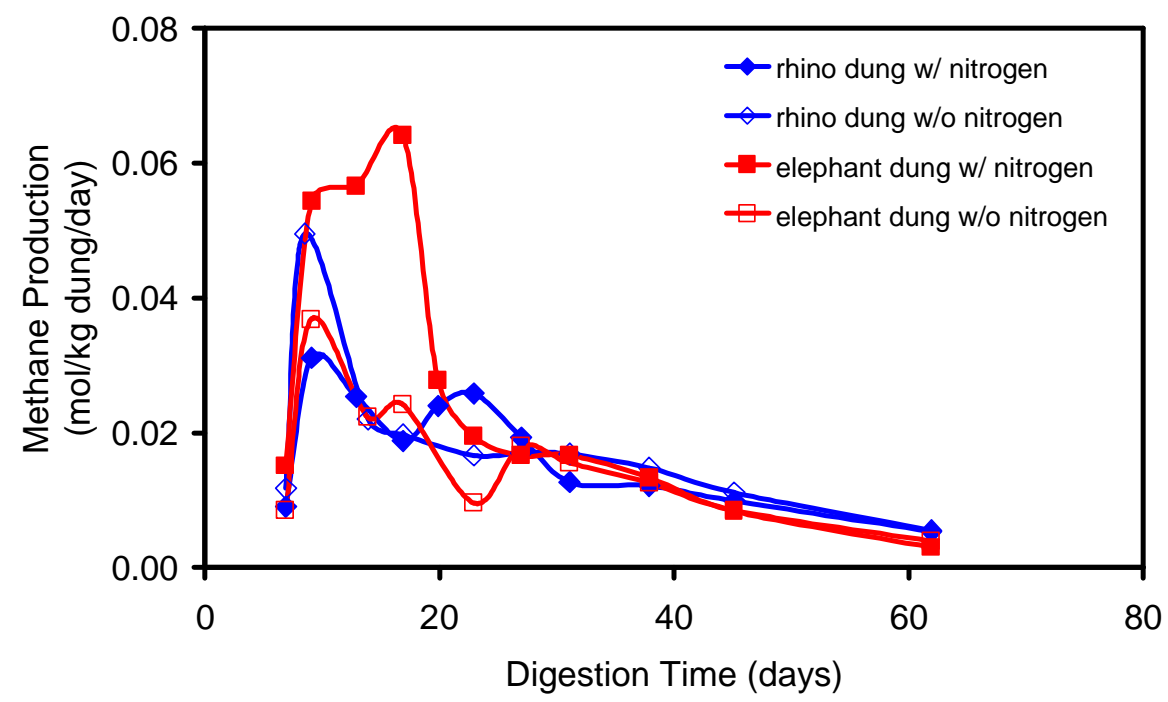

Fig. 9. Biogas production in second set of digesters incubated at $37^{\circ} \mathrm{C}$. 


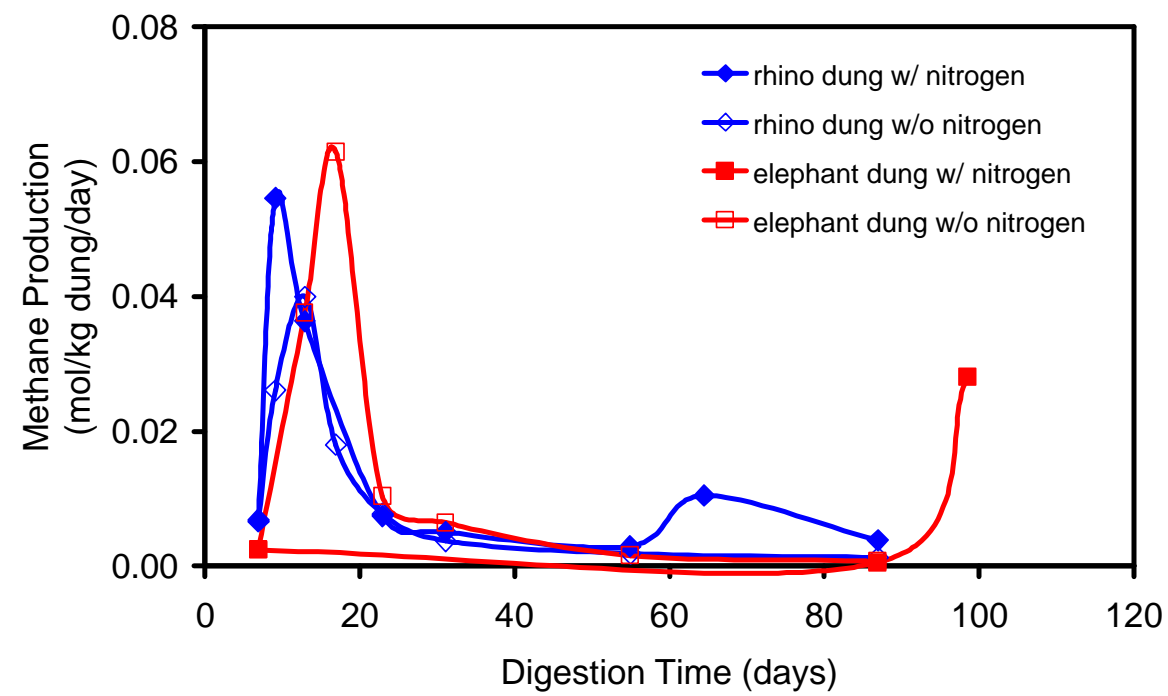

Fig. 10. Methane production in the second set of digesters incubated at $50^{\circ} \mathrm{C}$.

The biogas methane content for the digesters incubated at 37 and $50^{\circ} \mathrm{C}$ is shown in Fig. 11 and Fig. 12. As noted, the methane concentration in digesters incubated at $37^{\circ} \mathrm{C}$ was fairly constant, around $60 \%$. The methane concentration was higher at the elevated temperature $\left(50^{\circ} \mathrm{C}\right)$ during the initial part of the incubation, but it dropped toward the end of the incubation period.

Table 3. Biogas and methane yields in digesters with and without nitrogen supplement at two different incubation temperatures

\begin{tabular}{|c|c|c|c|c|c|c|c|}
\hline \multirow[b]{2}{*}{ Digester } & \multirow{2}{*}{$\begin{array}{c}\text { Dung } \\
\text { (g) }\end{array}$} & \multirow{2}{*}{$\begin{array}{c}\text { TVS } \\
(\mathrm{g})\end{array}$} & \multirow{2}{*}{$\begin{array}{l}\text { Biogas } \\
\left(\mathrm{L}_{\text {STP }}\right)^{*}\end{array}$} & \multirow{2}{*}{$\begin{array}{c}\mathbf{C H}_{4} \\
\left(\mathrm{~L}_{\mathrm{STP}}\right)\end{array}$} & \multicolumn{3}{|c|}{ Yields } \\
\hline & & & & & (L biogas/g dung) & ( $\mathrm{L} \mathrm{CH}_{4} / \mathrm{g}$ dung) & $\left(\mathrm{L} \mathrm{CH}_{4} / \mathrm{g}\right.$ TVS $)$ \\
\hline $\begin{array}{l}\text { Rhinoceros dung } \\
\text { w/ nitrogen at } 37^{\circ} \mathrm{C}\end{array}$ & 37.5 & 6.1 & 1.17 & 0.69 & 0.031 & 0.019 & 0.11 \\
\hline $\begin{array}{l}\text { Rhinoceros dung } \\
\text { at } 37^{\circ} \mathrm{C}\end{array}$ & 37.5 & 6.1 & 1.23 & 0.72 & 0.033 & 0.019 & 0.12 \\
\hline $\begin{array}{l}\text { Elephant dung } \\
\text { w/ nitrogen at } 37^{\circ} \mathrm{C}\end{array}$ & 37.5 & 5.7 & 1.59 & 0.99 & 0.042 & 0.026 & 0.17 \\
\hline $\begin{array}{l}\text { Elephant dung } \\
\text { at } 37^{\circ} \mathrm{C}\end{array}$ & 37.5 & 5.7 & 0.98 & 0.61 & 0.026 & 0.016 & 0.11 \\
\hline $\begin{array}{l}\text { Rhinoceros dung } \\
\text { w/ nitrogen at } 50^{\circ} \mathrm{C}\end{array}$ & 37.5 & 6.1 & 1.02 & 0.57 & 0.027 & 0.015 & 0.093 \\
\hline $\begin{array}{l}\text { Rhinoceros dung } \\
\text { at } 50^{\circ} \mathrm{C}^{\prime \prime}\end{array}$ & 37.5 & 6.1 & 0.74 & 0.41 & 0.020 & 0.011 & 0.068 \\
\hline $\begin{array}{l}\text { Elephant dung } \\
\text { w/ nitrogen at } 50^{\circ} \mathrm{C}\end{array}$ & 37.5 & 5.7 & 0.57 & 0.32 & 0.015 & 0.009 & 0.060 \\
\hline $\begin{array}{l}\text { Elephant dung } \\
\text { at } 50^{\circ} \mathrm{C}\end{array}$ & 37.5 & 5.7 & 1.21 & 0.56 & 0.032 & 0.015 & 0.097 \\
\hline
\end{tabular}




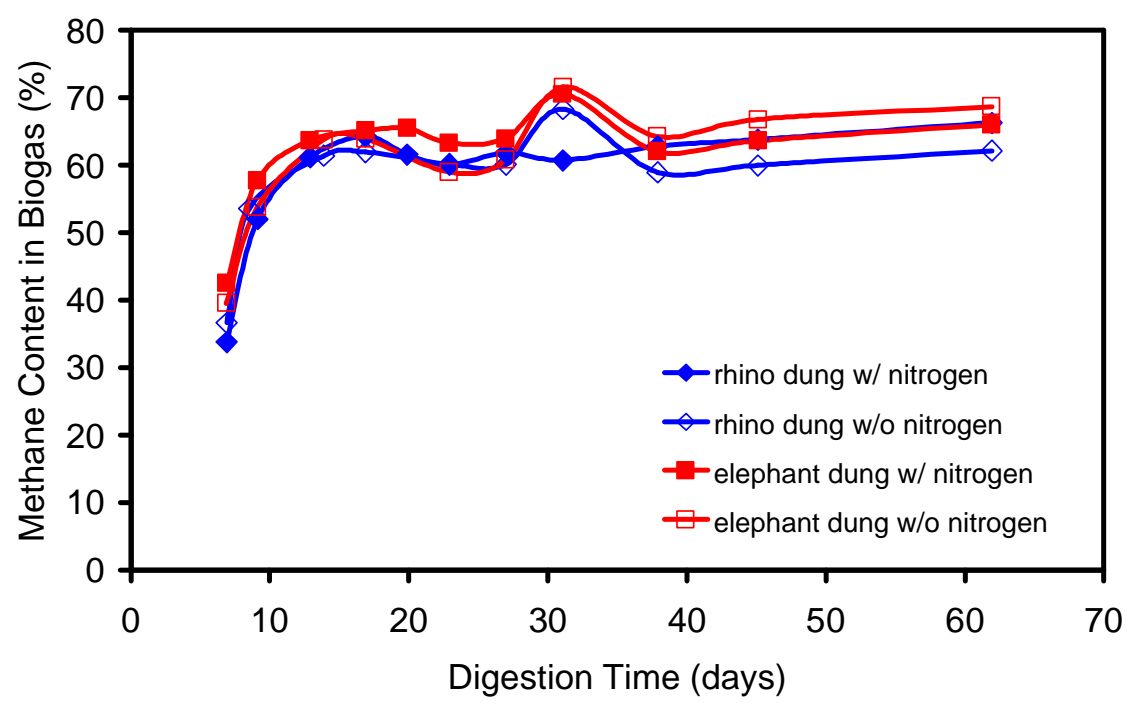

Fig. 11. Biogas methane content in digesters incubated at $37^{\circ} \mathrm{C}$.

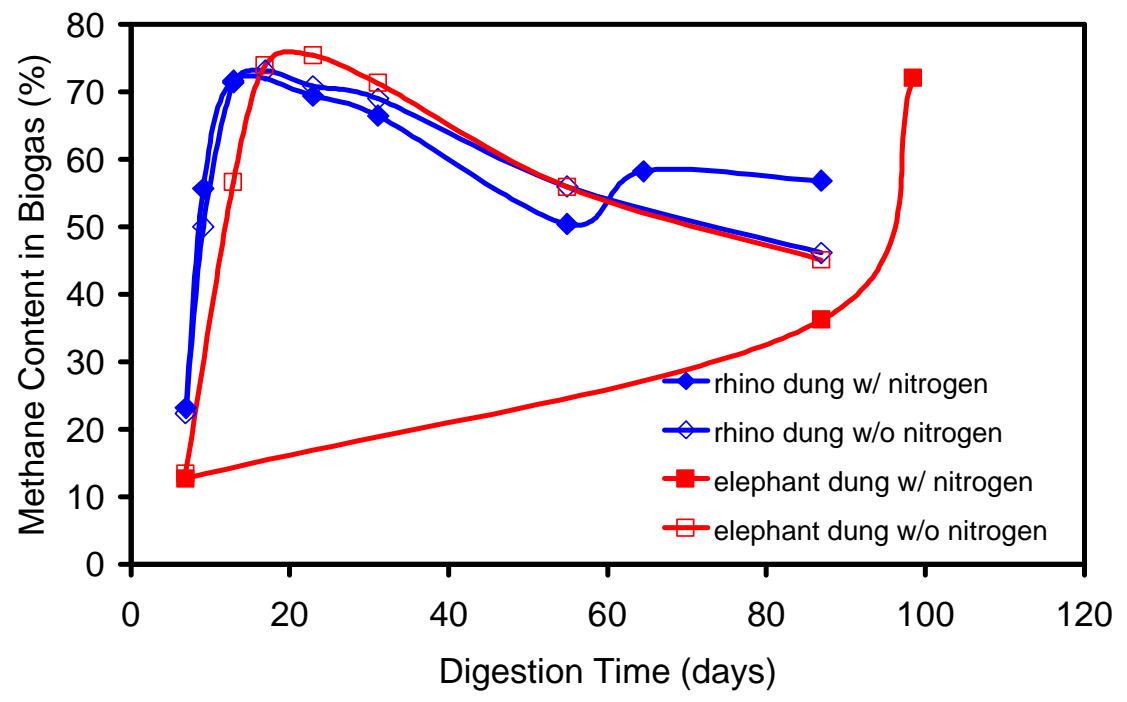

Fig. 12. Biogas methane content in digesters incubated at $50^{\circ} \mathrm{C}$.

\subsection{ESTIMATED BIOGAS ENERGY AVAILABILITY AT THE KNOXVILLE ZOO}

The Knoxville Zoo produces 30 cubic yards $\left(23 \mathrm{~m}^{3}\right)$ of herbivore dung per week and cost of disposal of this dung is $\$ 105 /$ week. ${ }^{7}$ The estimated weight of this dung is 20 metric ton per week or approximately 1050 ton/year, assuming a density of $0.88 \mathrm{ton} / \mathrm{m}^{3}$. This annually generated dung contains approximately 158 ton of TVS, which could potentially generate $17,400 \mathrm{~m}^{3}$ methane and the energy value for this methane is $6.6 \cdot 10^{8}$ $\mathrm{kJ}\left(6.2 \cdot 10^{8} \mathrm{Btu}\right){ }^{8}$ This amount of energy is not enough to generate electricity through a combustion engine or gas turbine $;{ }^{9}$ however, the gas could be used for two standard garden grills rated at approximately 40,000 $\mathrm{Btu} / \mathrm{h}$ each and operating $24 \mathrm{~h}$ per day. ${ }^{10}$ 


\section{CONCLUSIONS}

Elephant and rhinoceros dung was used to investigate the feasibility of generating methane from the dung. The methane yield on the dung was approximately $0.033 \mathrm{~L} \mathrm{biogas} / \mathrm{g}$ dung $\left(0.020 \mathrm{~L} \mathrm{CH}_{4} / \mathrm{g}\right.$ dung $)$, and the digestion of elephant dung was enhanced by the addition of ammonium nitrogen. Digestion was better overall at $37^{\circ} \mathrm{C}$ when compared to digestion at $50^{\circ} \mathrm{C}$. Based on the amount of dung generated at the Knoxville Zoo, it is estimated that two standard garden grills could be operated using the gas from a digester treating 20 metric tons of herbivore dung per week.

\section{REFERENCES}

1. A. Robinson, L. Baxter, H. Junker, C. Shaddix, M. Freeman, R. James, and D. Dayton, Fireside Issues Associated with Coal-Biomass Cofiring, NREL/TP-570-25767, National Renewable Energy Laboratory, Golden, CO, 1988.

2. V. N. Gunaseelan, "Anaerobic Digestion of Biomass for Methane Production: A Review," Biomass and Bioenergy 13, 83-114 (1997).

3. T. Mandal and N. K. Mandal, "Comparative Study of Biogas Production from Different Waste Materials," Energy Convers. Mgmt. 38, 679-683 (1997).

4. P. W. Gibson (Bienergy Organizers, Inc., Baltimore, MD), Baltimore Zoo Digester Project: Final Report, DOE/R3/06058-T1, U.S. Department of Energy, 1980.

5. Associated Press, "Elephant Dung Gets Powerful Use," The Commercial Appeal, Memphis TN, March $5,2000$.

6. A System Approach to Biogas Technology, in Biogas Technology: A Training Manual for Extension, Food and Agriculture Organization of the United Nations/Consolidated Management Services, Kathmandu, Nepal, 1996.

7. P.M.M. Roddy, Knoxville Zoological Gardens, Knoxville, TN, letter to N.P. Nghiem, Oak Ridge National Laboratory, June 29, 1999.

8. The TVS content is assumed to be $15 \%$ (Table 1), the yield of methane on TVS was assumed to be 0.11 $\mathrm{L} / \mathrm{g}$ (Table 3), and the energy value for methane is $37,700 \mathrm{~kJ} / \mathrm{m}^{3}$.

9. P. Lusk, Methane Recovery from Animal Manures, The Current Opportunities Casebook, NREL/SR580-25145, National Renewable Energy Laboratory, Golden, CO, 1998.

10. The methane potential for the zoo waste was $6.2 \cdot 10^{8} \mathrm{Btu} / \mathrm{year}$ or $71,000 \mathrm{Btu} / \mathrm{h}$. 
ORNL/TM-2003/51

\section{INTERNAL DISTRIBUTION}

1. M. A. Brown

2. B. H. Davison

3. S. R. Dresher

4. M. A. Karnitz

\author{
5. K. T. Klasson \\ 6. Central Research Library \\ 7. ORNL Laboratory Records-RC \\ 8. ORNL Laboratory Records-OSTI
}

\section{EXTERNAL DISTRIBUTION}

9. B. B. Bock, TVA Public Power Institute, P.O. Box 1010, Muscle Shoals, Alabama 35662

10. B. D. Hensley, Energy Division, Department of Economic and Community Development, Department of Tennessee, 312 Eight Ave., North, Nashville, TN 37243

11. K. Montgomery, Knoxville Zoological Gardens, P.O. Box 6040, Knoxville, TN 37914

12. N. P. Nghiem, MBI International, 3900 Collins Road, Lansing, MI 48910

13. C. Oliphant, Energy Division, Department of Economic and Community Development, Department of Tennessee, 312 Eight Ave., North, Nashville, TN 37243

14. J. Sicard, GEM Technologies, 212 South Peters Road, Suite 202, Knoxville, TN 37923 